\title{
Effects of Business Model Development Projects on Organizational Culture: A Multiple Case Study of SMEs
}

\author{
Ulla Santti, Tuomo Eskelinen, Mervi Rajahonka, \\ Kaija Villman, and Ari Happonen
}

\author{
"Change is the law of life. And those who look only") \\ to the past or present are certain to miss the future.
}

John F. Kennedy (1917-1963)

35th President of the United States

\begin{abstract}
Previous research has shown that links between organizational culture and innovativeness/performance may act as a "social glue" that helps a company develop organizational culture as a competitive advantage. In this study of three case companies, the organizational culture change due business model development projects is studied using the Competing Values Framework (CVF) tool and interviews with respondents about discovered changes. To reveal intervention and implied effects between business model development project and organizational culture changes, we used CIMO logic (context, intervention, mechanism, and outcome) to bridge practice and theory by explanatory, backward-looking research. Our case studies of companies in relatively short-duration business model development projects indicate that organizational culture may have some dynamic characteristics, for example, an increase of the adhocracy organizational type in all case companies or an increase in the hierarchical leadership type in one case company. Thus, the development of an organizational culture type can be partly controlled. Our results also indicated business model development projects do have a minor effect on organizational culture, even when development activities have not been put fully into practice. However, the more comprehensively business model development project activities have been put into practice, the larger the effect on organizational culture.
\end{abstract}

\section{Introduction}

Entrepreneurs tend to say it is more important for new employees to fit in with the group and the company culture than to have the best grades at university., For example, according to Macdonald, Assimakopoulos, and Anderson (2006), managers of small and medium-sized enterprises (SMEs) value an employee's natural ability and job experience more than their formal training . When a new employee starts to work in a firm, the first thing to learn is "how they do things" in terms of the firm's unspoken values, norms, and beliefs. In other words, the first thing to learn in a new job is organizational culture. However, researchers have faced complexity in defining organizational culture. In this work, organizational culture means organizational values, predictions, and beliefs in doing business (Barney, 1986; Schein, 1990) and shared perceptions of daily practices (Hofstede et al., 1990). In today's business world, employees are expected to have adaptability, skills and knowledge, and ability to solve complex problems with multiple methods. In general, anyone who has ever travelled knows the potential of our world's existing cultures in terms of understanding, communication, and the effects of culture on group work (Schein, 1985). Therefore, organizational culture and skillful employees are valuable resources in building a competitive advantage that is unique and difficult to copy by other companies because it is rare and imperfectly imitable (Barney, 1986; Chatman \& Chen, 1994). 


\title{
Effects of Business Model Development Projects on Organizational Culture
}

\author{
Ulla Santti, Tuomo Eskelinen, Mervi Rajahonka, Kaija Villman, and Ari Happonen
}

Schein (1985) thought over 30 years ago that it is possibly the most important task of all to create and manage organizational culture and that the ability to work with culture makes the most talented leaders. Schein (1984) also had underlined the importance of understanding the dynamic evolutionary forces effecting cultural changes. "Corporate leadership and corporate culture have to be aligned to market realities to ensure the long-term success of a firm"(Koplyay et al., 2013). Researchers have highlighted the positive impact of organizational culture on the performance of organization (Deshpandé \& Farley, 2004; Deshpandé et al., 2000), and identify those organizations having a culture favouring innovativeness and creativity as the most innovative in the market (Ahmed, 1998). The ability to adopt new knowledge is a precedent factor in improving an organization's innovativeness (Hult et al.,2004). Homburg and Pflesser (2000) found that market-orientated culture influences performance indirectly through market performance. Still, few organizations take advantage of internal marketing opportunities in predicting changes in their business environments, because they do not have this type of organizational culture (Gounaris, 2006). Today, renewing organizational culture is essential for businesses and especially it is a key aspect to innovativeness (Matinaro \& Yang, 2017; Valencia, 2010).

Competitive and innovative cultural traits have a direct link with company performance, but the cultural traits of bureaucracy and leadership style do not directly relate to organizational performance (Ogbonna \& Harris, 2000). Strong organizational culture and ability for transformation are connected to better performance, and, based on that, it is possible to predict short-term performance (Gordon \& DiTomaso, 1992). The organizational culture may fuel the development of institutional processes (Tsui et al., 2006). Organizational culture develops over the years and stabilizes uncertainty, but once it has been created, it is hard to change within a short timetable without replacing the people in the group (Demers, 2007; Frost et al., 1991). Unfortunately, there are no convincing conceptual models that clearly demonstrate how the change happens at a deeper level and how behavioural change can ultimately lead to cultural change (Ogbonna, 1992).

The organizational culture consists of shared values, predictions, and beliefs concerning how to make the business successful and stabilize working life - and strong organizational culture affects both the innovativeness and performance of the company (Barney, 1986; Hofstede et al., 1990; Schein, 1990). Also, Schein's wellknown model of building an organizational culture har- nesses the effects of values in innovative behaviour (Hogan \& Coote, 2014). And, recently, Guimaraes and colleagues (2017) listed 14 culture traits under four headings (organizational awareness, seeking improvement, goal achievement, and trust and cooperation) to measure cultures conductive to innovation. Also, Lakiza, Deschamps, and Brodeur (2017) found a complex relationship between organizational culture, performance measurement systems, and innovation capabilities, which would be important to investigate in organizational contexts. If we look at this the other way around and develop innovativeness and performance in the company by business model development project, new working methods and training for employees, we can consider the possibility that these development activities also have an effect on organizational culture. According to Ragan (2013), innovative thinking is possible to strategically "program" into organizational culture with clarity and discipline and by developing a culture that rewards experimentation and learning through doing. Thus, we can argue that organizational culture is likely to impact an SME's business model development project activities, which can then lead to changes in its organizational culture.

Any kind of change in relationships and connections between people and interpretations is a change in organizational culture, and the change is considered as uncontrollable evolutionary change from unlocked processes (Denison, 2007). To study what organizational culture means for SMEs when developing their business models, this study synthesizes research analyses based on data from the Pake Savo and Akseli projects. Our research hypothesis was that the specific underlying organizational culture changes due to influences of a business model development project. Based on case studies and a review of relevant literature, we argue that the relationship between organizational culture and putting business model development project activities into practice exists in changes in values and beliefs to make new things happen in organizations, and we argue that changes to organizational culture can be partly controlled.

In this study, we collected data using four questions based on the four value types (Figure 1) described by the Competing Values Framework (CVF) (Cameron \& Quinn, 2006). The CVF has previously been used, for example, to examine the organizational concept (Dasmalchian et al., 2000), to diagnose organizational culture (Igo \& Skitmore, 2005), to explore paradoxical leadership (Lavine, 2014), to study value perceptions and efficiency expectations in relation to organizational 


\section{Effects of Business Model Development Projects on Organizational Culture}

\section{Ulla Santti, Tuomo Eskelinen, Mervi Rajahonka, Kaija Villman, and Ari Happonen}

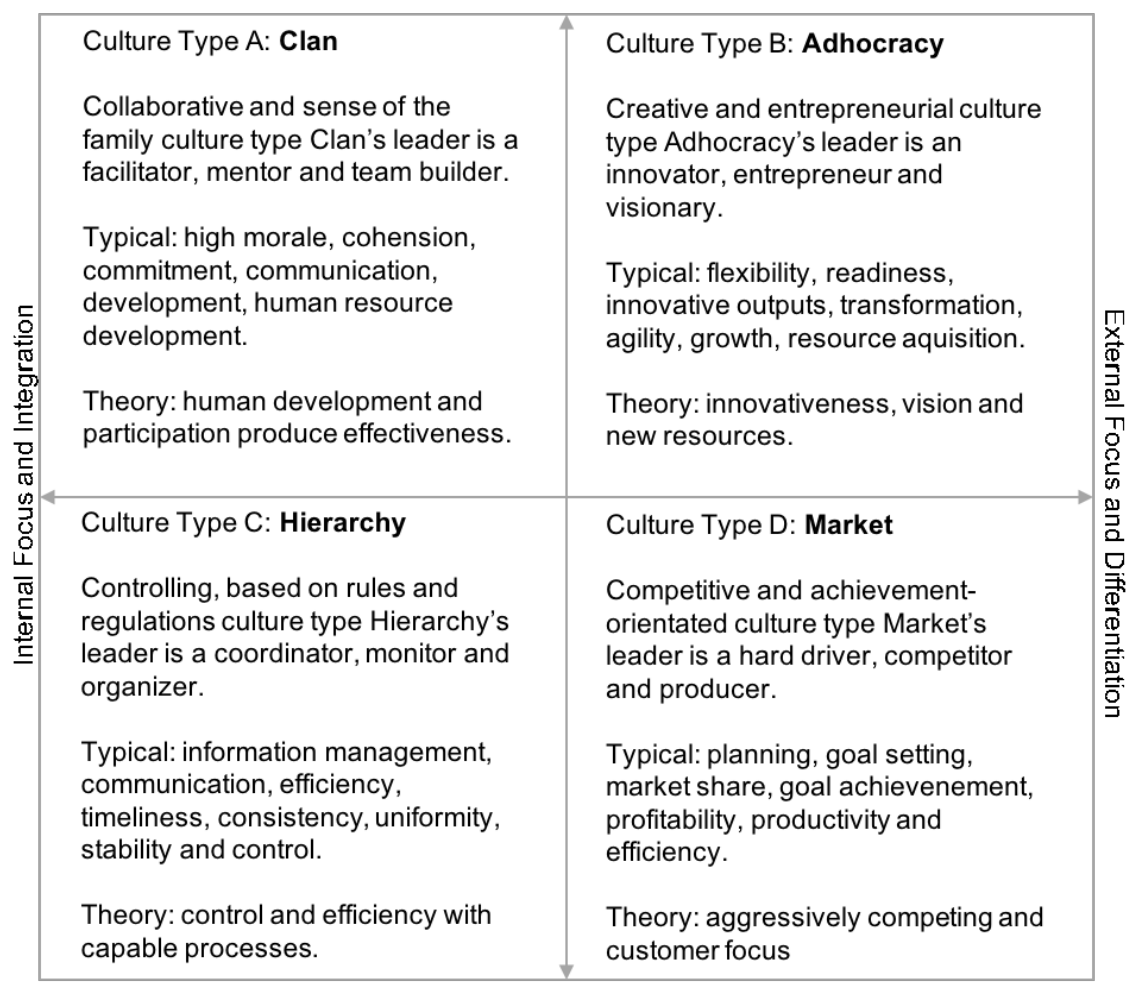

Stability and Control

Figure 1. The competing values framework (CVF): values in leadership, effectiveness and organizational theory. (Adapted from Cameron \& Quinn, 2006; Deshpande et al., 1993; and Yu \& Wu, 2009)

commitment (Van Vuuren et al., 2007), and to examine how organizations can improve global strategic performance (Lincoln, 2010). In this study, the CVF is used to identify changes in organizational culture.

Organizational culture can act as a "social glue" - a force that holds an organization together (Smircich, 1983). This force of organizational culture can either advance or diminish creativeness and innovativeness in a company (Martins \& Terblanche, 2003). Despite various definitions (e.g., Barney, 1986; Hofstede et al., 1990; Schein, 1990; Smircich, 1983), researchers tend to study cultural change based on as relatively superficial aspects, such as logos, ceremonies, and mission statements (Demers, 2007). This research purely concentrated on changes in organizational culture types based on the CVF (Figure 1).

The competing values framework (CVF) was originally developed by Quinn and Rohrbaugh (1981) to explain differences in competing values research (Denison \& Spreitzer, 1991), and it has undergone further development by various researchers (Cameron \& Freeman,
1991; Cameron \& Quinn, 2006; Deshpandé et al., 1993; Quinn et al. (1991), and). The underlying idea in the CVF is that organizational culture is not homogenous but is instead a combination of competing values. There are four types: 1) a clan: a collaborative organization, with open team spirit; 2) an adhocracy: an entrepreneurial and creative organization with risk-taking and fast-moving ability; 3) a hierarchy: with coordinated processes and efficient operations; and 4) a market: with active focus on customers and competing aggressively in the market. A company's organizational culture is typically a combination, having features from all of these four culture types. As criticism, Hartnell, Ou, and Kinicki (2011) found varying relationships between three culture types and efficiency, together with how different strategies fit with certain culture types to attain competitive advantage. However, a factor analysis of 300 hospital managers has given convincing evidence of the CVF's reliability and validity (Kalliath et al., 1999). And it has been used in a variety of settings, including studies of organizational culture in European companies (Van Muijen, 1999) and managerial perceptions among Australian managers (Lamond, 2001). 


\title{
Effects of Business Model Development Projects on Organizational Culture
}

\author{
Ulla Santti, Tuomo Eskelinen, Mervi Rajahonka, Kaija Villman, and Ari Happonen
}

Using this framework, the respondent evaluates the situation before and after an intervention and determines whether changes in culture type have taken place. A questionnaire is filled in by the respondent during an interview focused on explaining the reasons behind any changes in culture type. Finally, we used CIMO logic (context, intervention, mechanism, outcome) (Denyer et al., 2008) to explore intervention effects and synthesize information from the practical project work. CIMO logic has been used in other studies to draw causal relationships between an intervention and the outcome within a particular context (Bougharas et al., 2010; Brouwer et al., 2012; Rajwani et al., 2015; Pries-Heje \& Baskerville, 2010).

\section{Research Questions and Methods}

Our three research questions are as follows:

1. Which organizational culture types prevail among the SMEs participating in the Pake Savo and Akseli business model development projects?

2. In which direction has the organizational culture of SMEs changed due to a business model development project?

3. Which business model development project activities have affected organizational culture, as evidenced by CIMO logic?

We interviewed the management and employees of SMEs participating in two business development projects: Pake Savo and Akseli. There were six respondents altogether: two from case company 1 (Ergo-Kalusteet), one from case company 2 (Autorobot), and three from case company 3 (Chasswheel). We asked each respondent four questions (see Table 1) based on the CVF to assess their organizational culture before and after the project. If the respondent noticed some changes occurred in their organizational culture, we discussed these changes with them during the interviews to discover possible reasons why they might have occurred. For each question, respondents were asked to distribute 100 points across the four organization culture types by giving more points to the type that best described their organization, and fewer points to other types (Table 1).

The last phase is to draw cases together using CIMO logic to increase the practical relevance of solution-orientated prescriptive knowledge by problematic Context (C), Intervention type (I), generative Mechanism (M) and the Intended outcome(s) (O) (Denyer et al., 2008), to reveal interventions, implied effects, and effects on the case company's organizational culture. Organizational culture changes are not necessarily intended outcomes, but rather the needed side effect of business model development. CIMO logic is developed for structuring new and interesting means-ends propositions that help bridge practice and theory through explanatory backward-looking research (Holmström et al., 2010). In this study, the method is used to formulate explanations for how interventions produce outcomes in the Pake Savo and Akseli business model development projects.

\section{Business Model Development in the Case Companies}

The objectives of the Akseli and Pake Savo projects were to increase effectiveness of work processes, modernize the SMEs' business models, and encourage customer orientation by involving customer into development processes, for example product development. The Service Logic Business Model Canvas works particularly well as a discussion tool in creating a more customer-centered business culture because it places the customer at the centre of all elements in the business model canvas (BMC) (Miettinen, 2017). Both projects included an innovation process based on the InTo business model analysis tool (into.savonia.fi) (see Kajanus et al., 2014), which has six phases (Eskelinen et al., 2017; Kajanus et al., 2014):

\section{Context and goal design}

2. Idea generation and collection

3. Idea collection into the InTo web-based innovation tool

4. Idea evaluation according to evaluation criteria with InTo

5. A core index decision-making analysis to prioritize ideas

6. Selection of the best ideas to progress toward the goal defined in phase 1

Pake Savo was a joint project of the South-Eastern Finland University of Applied Sciences XAMK and the Savonia University of Applied Sciences, which included 25 participating companies. The project aimed at helping SMEs located in the Northern Savo (Eastern Finland) region to start or develop their service business. The Pake Savo project arranged two training packages on service business design for the SMEs. In addition to 


\section{Effects of Business Model Development Projects on Organizational Culture}

\section{Ulla Santti, Tuomo Eskelinen, Mervi Rajahonka, Kaija Villman, and Ari Happonen}

Table 1. Questions used for the classification of organization culture before and after the project (based on Deshpandé et al., 1993). For each question, respondents were asked to distribute 100 points across the four types.

1. Type of organization (Please distribute 100 points)

A) My organization is a very personal place. It is like extended family. People share a lot of themselves.

B) My organization is a very dynamic and entrepreneurial place. People are willing to stick their necks out and take risks.
C) My organization is a very formalized and structured place. Established procedures generally govern what peopledo.

D) My organization is very production orientated. A major concern is with getting the job done, without much personal involvement.

2. Leadership (Please distribute 100 points)

A) The head of my organization is generally considered to be a mentor, sage or father/mother figure.

B) The head of my organization is generally considered to be entrepreneur, an innovator, or risk taker.
C) The head of my organization is generally considered to be coordinator, an organizer, or an administrator.

D) The head of my organization is generally considered to be a producer, a technician, or a hard-driver.

3. What holds the organization together? (Please distribute 100 points)

A) The glue that keeps my organization together is loyalty and tradition. Commitment to this firm is high.

B) The glue that holds my organization together is commitment to innovation and development. The goal is to be the first.
C) The glue that holds my organization together is formal rules and policies. Maintaining a smooth-running institution is important here.

D) The glue that holds my organization together is accomplishment at tasks and goals. Production orientation is commonly shared.

4. What is important? (Please distribute 100 points)

A) My organization emphasizes human resources. High cohesion and morale are important.

B) My organization emphasizes growth and acquisition of new resources. Readiness to meet new challenges is important.
C) My organization emphasizes permanence and stability. Efficient, smooth operations are important.

D) My organization emphasizes competitive actions and achievement. Measurable goals are important. participating in the training sessions, the companies carried out individual development projects on each company's service business. In these development projects, the participants learned to apply the service design methods and the business model approach to their companies. Several of the participating SMEs applied a service design approach in their company to develop new innovative products and services. Many of the companies used the InTo business model analysis tool (Kajanus et al., 2014) to select the development project or to prioritize key development targets. The development projects implied that the shift from a product-oriented company to a customer-or service- oriented company cannot succeed without a significant change in the organization's culture (Eskelinen et al., 2017). Two of the case companies in this research project were participants in the Pake Savo project.

The Akseli project was to help SMEs develop their business models in the Northern Savo area based on their business needs. Therefore, the results from company 1 , Ergo-Kalusteet, reflect the needs and visions of the participating growth/development-orientated SMEs. Seven SMEs participated in Akseli project development activities with two main tools: extended business model canvas presented in Kajanus and colleagues (2014), which 


\title{
Effects of Business Model Development Projects on Organizational Culture
}

\author{
Ulla Santti, Tuomo Eskelinen, Mervi Rajahonka, Kaija Villman, and Ari Happonen
}

has company solution and competitive solutions added to the business model canvas and the InTo business model analysis tool (Kajanus et al., 2014) to discover and evaluate development ideas together with employees, management, and customers. Internet marketing and social media development activities were discovered in many participating SMEs. Based on that finding, they were provided with consulting and Internet marketing training sessions, which included social media training.

\section{Results and Discussion}

\section{Case company 1: Ergo-Kalusteet}

Case company 1, Ergo-Kalusteet (www.ergo-kalusteet.fi) has operated a furniture business since 1988 and has gained extensive expertise in design, production, and materials (e.g., wood, plastic, and especially corian, a hygienic surface material). Constant training and modern equipment keeps the company competitive in their field. "Our objective was to develop our internal communication to make our manufacturing and marketing departments more co-operative and efficient", stated the Chairman of the Board. Our results for this case company clearly show there was major influence made by the intervention, and the development activities have mostly been successfully put into practice in the organization (Figure 2). Ergo-Kalusteet has ambitious intentions to grow, and their expansion has already started, with new investments raising the risk level, which explains some of the growth of the adhocracy organizational culture type. Job descriptions became clearer and operations became better organized after the intervention, therefore the hierarchy culture type increased, becoming the second major culture type in the company (Figure 2). Respondents also commented that employees' commitment had increased because of clearer work tasks with better and timely instructions. The development of a communication culture changed many, even unexpected things for

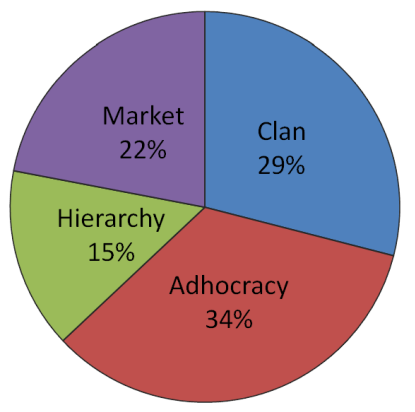

Before Intervention

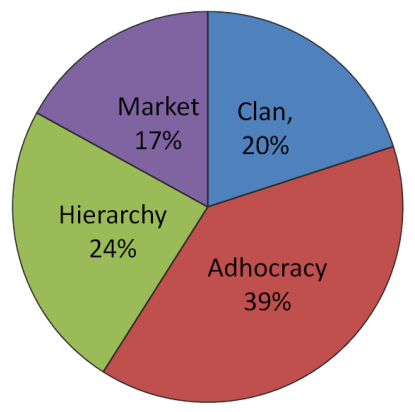

After Intervention
Figure 2. Ergo-Kalusteet culture types before and after intervention better direction. For example, they found they were better able to organize production, communicate openly, and share personal issues, while also communicating more formally. "Cultural change may have been bigger for senior employees, although it was also a big change for the younger generation, because we were not used to using these communication tools at work even though we use them constantly in our free time," stated the production manager from the case company.

\section{Case company 2: Autorobot}

Product development has been the foundation of Autorobot (www.autorobot.com), which manufactures and markets collision repair equipment and measuring systems. This 48-year-old family-owned business has around 100 patents and exports to 70 countries worldwide. The company participated in the Pake Savo project to learn more about service design thinking to progress customer orientation in its processes, improve internal communication, and support other development projects to modernize its production and machinery. The Pake Savo project provided training and coaching, business model and service design with Savonia Innovation Tool (InTo), and consultancy for opening a webstore.

"Pake Savo training and small group coaching gave us a different view to modernize operations and also new ideas we would never thought of, and especially InTo brought new excitement for us," stated the marketing designer of the company, who also credited the employees' long work history (20-30 years) for bringing them together as a team. Autorobot has a need to become more of an adhocracy type of organization and less of the hierarchy type, which has clearly, with small impact, happened due its participation in the business model development project (Figure 3).
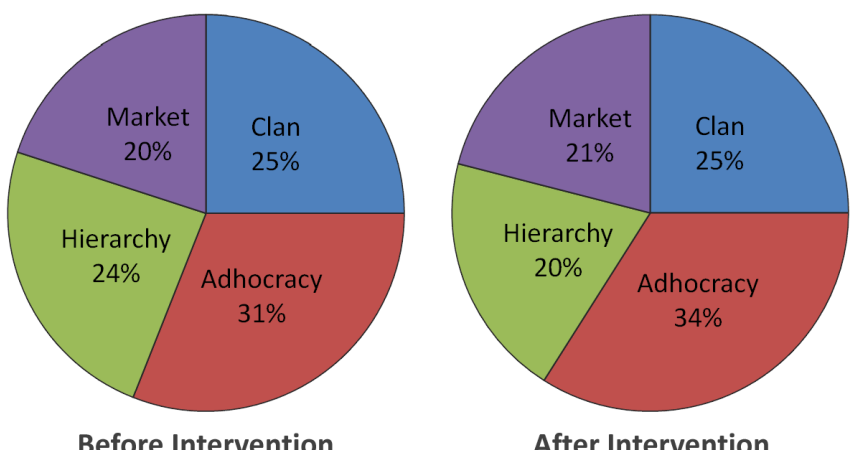

After Intervention

Figure 3. Autorobot culture types before and after intervention 


\section{Effects of Business Model Development Projects on Organizational Culture}

\section{Ulla Santti, Tuomo Eskelinen, Mervi Rajahonka, Kaija Villman, and Ari Happonen}

\section{Case company 3: Chasswheel}

Since 1995, Chasswheel (chasswheel.com) has made electric wheelchairs that are now sold in 10 countries. Its products feature a durable and flexible "Four X" chassis solution that allows the end user to stand, drive, and even cross over small obstacles at the same time (Figure 4).

Chasswheel participated in the Akseli project to find innovative ideas to develop its business model and generate ideas for sales and marketing. "We have a lot of enthusiasm and ideas for business model development project activities. Social media appeared as the most important marketing channel to reach our end users and spread our word forward," said the company's CEO. In the Akseli project, SMEs received consultation for business model development from Lappeenranta University of Technology and Savonia University of Applied Sciences, and a training session to develop skills and knowledge for Internet and social media visibility based on the results from the idea-screening process. With business model development activities, Chasswheel started to pursue a transformation from manufacturing towards sales and marketing and learned about the opportunities provided by social media in terms of getting closer to their products' end users. They also gained improved employee commitment and belief in the company's future success. All respondents from this case company mentioned that even more changes could have been finally put into practice because of the potential of a good plan, but crucial everyday operations took attention away from final the business model development. Organizational culture was wished to be improved in goal orientation, self-direction, internal communication, customer orientation, and innovativeness. Clan culture is considered as a strong and leading force that holds the organization together, and it did increase due to the Akseli project. The market culture type decreased, which can be explained by challenges in production, and which reflected the company's ability to meet the customer needs in delivery schedules at that time (Figure 5).

Chasswheel continued development activities after the Akseli project by reorganizing production and increasing connections with end users through social media channels, which may affect the market organizational culture type in the future.

\section{Business model development activities affected organizational culture}

The activities of the Pake-Savo and Akseli projects were evaluated together according to CIMO logic, as sum-
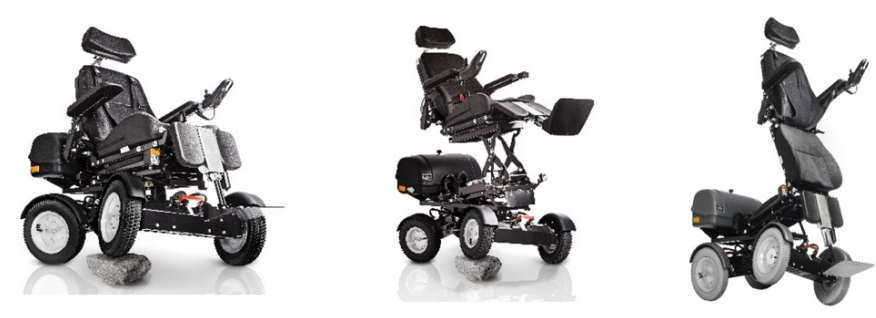

Figure 4. A Chasswheel multifunctional electric Four X wheelchair

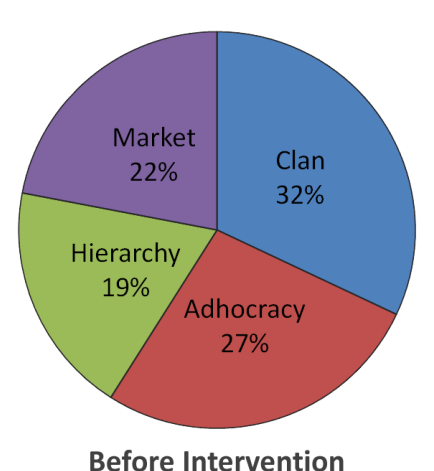

Before Intervention

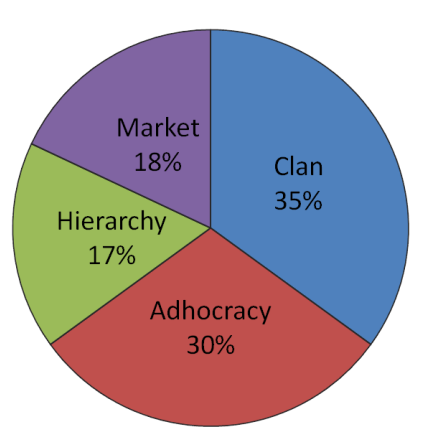

After Intervention
Figure 5. Chasswheel culture types before and after intervention

marized in Table 3, which shows how each company sought to find new ideas and solutions. Ergo-Kalusteet clearly focused more on developing internal communication by making communication processes more structured with mobile applications, which shifted their organization toward the hierarchical culture type. Autorobot also prioritized internal communication and the outcome was a list of future actions related to internal communications. New ideas and support from an external team seemed to influence the shift toward the adhocracy culture type, making the organization more entrepreneurial with increased risk-taking, responsiveness toward new ideas, and increased readiness for innovation. In Chasswheel, the identification of new ideas led to an increase in the adhocracy culture type. A new tool was put into the development process and social media marketing campaigns and actions were put into practice. In all these case companies, the leading organizational culture type was increased by the business model development project.

\section{Conclusion}

The case studies revealed the non-statistical nature of organizational culture even in a short time frame (measured in months, not years). This means that the culture has dynamic characteristics that are affected by 


\section{Effects of Business Model Development Projects on Organizational Culture}

\section{Ulla Santti, Tuomo Eskelinen, Mervi Rajahonka, Kaija Villman, and Ari Happonen}

Table 3. CIMO logic (cf. Denyer et al., 2008) applied to the participative business model development processes of the three case companies: Ergo-Kalusteet, Chasswheel, and Autorobot (Eskelinen et al., 2017)

\begin{tabular}{|c|c|c|c|}
\hline & 1. Ergo-Kalusteet & 2. Autorobot & 3. Chasswheel \\
\hline Context & $\begin{array}{l}\text { Company offering tailored wood } \\
\text { and composite-based products, } \\
\text { e.g. acoustical elements for } \\
\text { loudspeakers. Challenges in } \\
\text { developinginternal } \\
\text { communication between } \\
\text { production, marketing, and } \\
\text { delivery of products. }\end{array}$ & $\begin{array}{l}\text { Company designs, manufactures. } \\
\text { and markets repair equipment } \\
\text { and measuring systems for } \\
\text { repairing collision-damaged } \\
\text { vehicles. Challenges between } \\
\text { internal communication } \\
\text { production, marketing and sales } \\
\text { departments. }\end{array}$ & $\begin{array}{l}\text { Company designs and } \\
\text { manufacturers all-terrain electric } \\
\text { wheelchairs. Challenges in sales } \\
\text { and marketing. Has a regular } \\
\text { customer basis and sales channels } \\
\text { in Europe. }\end{array}$ \\
\hline Interventions & $\begin{array}{l}\text { Business model development } \\
\text { process to find new ideas and } \\
\text { solutions. }\end{array}$ & $\begin{array}{l}\text { Development process to find } \\
\text { ideas and solutions to develop } \\
\text { internal communication. }\end{array}$ & $\begin{array}{l}\text { Business model development } \\
\text { process to find new ideas and } \\
\text { solutions. }\end{array}$ \\
\hline Mechanisms & $\begin{array}{l}\text { A business model development } \\
\text { process: context definition, idea } \\
\text { creation with interviews and web } \\
\text { link, multi-criteriaidea evaluation } \\
\text { with a web based tool, portfolio } \\
\text { analysis of results and workshop }\end{array}$ & $\begin{array}{l}\text { A development process with six } \\
\text { questions on challenges in } \\
\text { internal communication, idea } \\
\text { creation in a workshop, external } \\
\text { expert visit to accelerate creation } \\
\text { of new ideas, idea evaluation with } \\
\text { a web tool, multi-criteria } \\
\text { evaluation of ideas, portfolio } \\
\text { analysis and a results workshop. }\end{array}$ & $\begin{array}{l}\text { A business model development } \\
\text { process: context definition, idea } \\
\text { creation with interviews and web } \\
\text { link, multi-criteriaidea evaluation } \\
\text { with a web based tool, portfolio } \\
\text { analysis of results, workshop and } \\
\text { internet marketing training. }\end{array}$ \\
\hline Outcome & $\begin{array}{l}\text { Two solutions were identified and } \\
\text { put into practice. A WhatsApp } \\
\text { application was tested and found } \\
\text { useful. }\end{array}$ & $\begin{array}{l}\text { Prioritized list of actions. A } \\
\text { decision was made to improve, } \\
\text { test and pilot an internal } \\
\text { communication system. }\end{array}$ & $\begin{array}{l}\text { New ideas identified with social } \\
\text { media marketing actions. A } \\
\text { wheelchair planning tool is in } \\
\text { development. }\end{array}$ \\
\hline $\begin{array}{l}\text { Organizational } \\
\text { Culture Effects }\end{array}$ & $\begin{array}{l}\text { Changes in all culture types. } \\
\text { Leading culture type adhocracy } \\
\text { increased } 5 \text { percentage points, in } \\
\text { line with their growth intentions. } \\
\text { Hierarchy type was minor type } \\
\text { before intervention and increased } \\
9 \text { percentage points becoming } \\
\text { second major culture type (larger } \\
\text { than expected change). } \\
\text { Communication development } \\
\text { increased formality. Clan } \\
\text { decreased } 9 \text { percentage points } \\
\text { and market } 5 \text { percentage points. }\end{array}$ & $\begin{array}{l}\text { Minor changes. Leading culture } \\
\text { type adhocracy increased and } \\
\text { minor culture type hierarchy } \\
\text { decreased. Changes were } \\
\text { welcomed by the company. }\end{array}$ & $\begin{array}{l}\text { Minor changes in all culture types. } \\
\text { Leading culture type of clan } \\
\text { increased } 3 \text { percentage points, as } \\
\text { well as adhocracy, which was a } \\
\text { desired change. Hierarchy } \\
\text { decreased } 2 \text { percentage points } \\
\text { and market decreased also } 4 \\
\text { percentage points. }\end{array}$ \\
\hline
\end{tabular}

new participants and enthusiasm due to project work. The organizational culture type effects may occur even due to short-term project work, the aim of which was to develop business models or business model service design. Effects on organizational culture were identified even though development plans were not entirely put into practice, so the effects do not represent the full development results. However, the results do indicate that change to an organization can occur early based on experience gains when the company is undergoing efforts in pursuit of change. We must consider also the positive effects of coaching (Fillery-Travis \& Lane, 2006) and increased motivation and knowledge due to teamwork (Mudambi et al., 2007), which causes the effect in 


\title{
Effects of Business Model Development Projects on Organizational Culture
}

\author{
Ulla Santti, Tuomo Eskelinen, Mervi Rajahonka, Kaija Villman, and Ari Happonen
}

our case studies results coming from working together as a team. The effects are results of working together and getting inside (tacit) knowledge of co-workers' values, ideas, and visions, which is also supported by Chen and Huang (2007), who showed that social interaction is positively related to knowledge management, and a study by Mathieu and colleagues (2000), who showed a fully mediating relationship between mental model and team effectiveness. Thus positive results generate new and improved atmosphere into the organizational culture or vice versa. However, the business model development project's effects on organizational culture were larger, once development activities were farther along.

In all the cases, the development of organizational culture took the direction towards the company management's preferred culture types. Therefore, organizational culture development may be partly controllable according to respondents with collaborative business model development project activities as idea development, training sessions, and team meetings for putting development activities into practice. Based on this result, we recommend restricting development activities more towards the most wanted culture type and to prioritize putting business model development project activities into practice to have the best possible impact. However, this study would benefit from a larger set of quantitative employee interviews. After all, if the management wishes for a certain type of change, they may see the change in the way they prefer (and respond accordingly during interviews). However, employees might have a different view, particularly if many are interviewed to overcome any management bias.

Business model development projects will not immediately change the organizational culture type, but those development activities can sow the seeds of change. For further research, we recommend studying whether these organizational culture changes are short-term changes or will develop further in the direction desired by company management. Another future research theme could identify which support actions are needed to lead a company towards certain organizational culture types.

\section{Acknowledgements}

We wish to thank case companies Ergo-Kalusteet, Autorobot, and Chasswheel for their valuable cooperation and support for this study.

\section{About the Authors}

Ulla Santti, MSc (Econ), has experience as a teacher of Business Administration and Marketing, and she is an expert on research, development, and innovation projects at the Savonia University of Applied Sciences in Finland. She has also undertaken SME business development through practical field work in healthcare, industrial factories, advertising, and the tourism industries. Currently, she is preparing her doctoral thesis at the Lappeenranta University of Technology, Finland. Her research interest includes business models and organizational culture development of SMEs with an interest in what kind of common ground, effects, and connections these concepts have on each other.

Tuomo Eskelinen, $\mathrm{PhD}$, works as an RDI Advisor at the Savonia University of Applied Sciences in Finland. His background is in Environmental Sciences, and his expertise and research interests include sustainable value networks, development of business partnerships, and sustainable business models. He organizes research, development, and innovation processes with enterprises and other organizations, with scientists, end users, and customers, from idea generation to business model development and commercialization. He has participated in more than $20 \mathrm{EU}$-funded projects in the fields of forestry, energy, food, water safety, and processing. He is experienced in performing and coordinating interdisciplinary, international, large-scale research projects, workshops and training.

Mervi Rajahonka, DSc (Econ), works as an RDI Advisor at the Small Business Center (SBC), currently a part of the South-Eastern Finland University of Applied Sciences XAMK, Finland. She has been working at the SBC for about 10 years, participating in numerous EU-funded projects. She earned her doctoral degree in Logistics from the Department of Information and Service Economy at Aalto University School of Business in Helsinki, Finland. She also holds a Master's degree in Technology from the Helsinki University of Technology and a Master's degree in Law from the University of Helsinki. Her research interests include sustainable logistics and supply chain management, business models, service modularity, and service innovations. Her research has been published in a number of journals in the areas of logistics, services, and operations management. 


\section{Effects of Business Model Development Projects on Organizational Culture}

\section{Ulla Santti, Tuomo Eskelinen, Mervi Rajahonka, Kaija Villman, and Ari Happonen}

Kaija Villman, MMus in Arts Management, works as a Project Manager at the South-Eastern Finland University of Applied Sciences XAMK, Small Business Center (SBC), Finland. She has been working at the SBC for about 7 years, participating in numerous EUfunded projects in the fields of creative industries, service development, and digitalization. She is experienced in coordinating interdisciplinary projects, workshops, and training and she acted as the Project Manager for the PaKe Savo Project.

Ari Happonen, DSc (Tech) is Head of Computer Science Bachelor programme in Innovation and Software at Lappeenranta University of Technology (LUT), Finland. Ari has been working for the LUT for more than 15 years, participating in numerous RDI projects with Finnish and international companies in the contexts of international logistics services, consumer products industries, service development, consultation, business development, mobile services, construction industries, digitalization, and so on. Ari has a long history working as an intermediate and collaboration facilitator in interdisciplinary projects, workshops, innovation facilitation, development mentoring, teaching, and training and has also acted as the LUT Project Manager for the Akseli project.

\section{References}

Ahmed, P. K. 1998. Culture and Climate for Innovation. European Journal of Innovation Management, 1(1): 30-43. https://doi.org/10.1108/14601069810199131

Barney, J. B. 1986. Organizational Culture: Can It Be a Source of Sustained Competitive Advantage? Academic Management Review, 11(3): 656-665.

http://www.jstor.org/stable/258317

Boucharas, V., van Steenbergen, M., Jansen, S., \& Brinkkemper, S. 2010. The Contribution of Enterprise Architecture to the Achievement of Organizational Goals: A Review of the Evidence. In E. Proper, M. M. Lankhorst, M. Schönherr, J.Barjis, \& S. Overbeek (Eds), Trends in Enterprise Architecture Research. TEAR 2010. Lecture Notes in Business Information Processing, 70. Berlin: Springer.

https://doi.org/10.1007/978-3-642-16819-2_1

Brouwer, P., Brekelmans, M., Nieuwenhuis, L., \& Simons, R. J. 2012. Fostering Teacher Community Development: A Review of Design Principles and a Case Study of an Innovative Interdisciplinary Team. Learning Environments Research, 15(3): 319-344. https://doi.org/10.1007/s10984-012-9119-1

Cameron, K., \& Freeman, S. 1991. Cultural Congruence, Strength, and Type: Relationships to Effectiveness. Research in Organizational Change and Development, 5: 23-58.
Cameron, K., \& Quinn, R. 2006. Diagnosing and Changing Organizational Culture: Based on Competing Values Framework. San Francisco, CA: Jossey-Bass.

Chatman, J. A., \& Jehn, K. A. 1994. Assessing the Relationship between Industry Characteristics and Organizational Culture: How Different Can You Be? Academy Management Journal, 37(3): 522-553.

http://doi.org/10.2307/256699

Chen, C. J., \& Huang, J. W. 2007. How Organizational Climate and Structure Affect Knowledge Management-The Social Interaction Perspective. International Journal of Information Management, 27(2): 104-118.

https://doi.org/10.1016/j.ijinfomgt.2006.11.001

Demers, C. 2007. Organization Change Theories: A Synthesis. Beverly Hills, CA: Sage Publications.

Denison, D. R., \& Spreitzer, G. M. 1991. Organizational Culture and Organizational Development: A Competing Values Approach. Research in Organizational Change and Development, 5: 1-21.

Denyer, D., Tranfield, D., Van Aken, J. E. 2008. Developing Design Propositions Through Research Synthesis. Organization Studies, 29(3): 393-413.

http://doi.org/10.1177/0170840607088020

Deshpandé, R., \& Farley, J. U. 2004. Organizational Culture, Market Orientation, Innovativeness, and Firm Performance: An International Research Odyssey. International Journal of Research in Marketing, 21(1): 3-22.

http://doi.org/10.1016/j.ijresmar.2003.04.002

Deshpandé, R., Farley, J. U., \& Webster, F. E. Jr. 1993. Corporate Culture, Customer Orientation and Innovativeness in Japanese Firms: A Quadrad Analysis. Journal of Marketing, 57(1): 23-37. http://doi.org/10.2307/1252055

Deshpandé, R., Farley, J. U., \& Webster, F. E. Jr., 2000. Triad Lessons: Generalizing Results on High Performance Firms in Five BusinessTo-Busines Markets. International Journal of Research of Marketing, 17(4): 353-362.

https://doi.org/10.1016/S0167-8116(00)00009-4

Eskelinen, T., Rajahonka, M., Villman, K., \& Santti, U. 2017. Improving Internal Communication Management in SMEs: Two Case Studies in Service Design. Technology Innovation Management Review, 7(6): 16-24.

http://timreview.ca/article/1081

Fillery-Travis, A., \& Lane, D. 2006. Does Coaching Work or Are We Asking the Wrong Question? International Coaching Psychology Review, 1(1): 24-36.

Frost, P. J., Moore, L. F., Louis, M. R., Lundberg, C. C., \& Martin, J. (Eds.) 1991. Reframing Organizational Culture. London: Sage Publications.

Gordon, G. G., \& DiTomaso, N. 1992. Predicting Corporate Performance from Organizational Culture. Journal of Management Studies, 29(6): 783-798.

https://doi.org/10.1111/j.1467-6486.1992.tb00689.x

Gounaris, S. P. 2006. Internal Market Orientation and Its Measures. Journal of Business Research, 59(4): 432-448. http://doi.org/10.1016/j.jbusres.2005.10.003

Guimaraes, T., Walton, M., \& Armstrong, C. 2017. A New Measure of Organizational Culture for Business Innovativeness in Practice. Paper presented at the ISPIM Innovation Forum, Toronto, Canada, March 19-22 March 2017. 


\section{Effects of Business Model Development Projects on Organizational Culture}

\section{Ulla Santti, Tuomo Eskelinen, Mervi Rajahonka, Kaija Villman, and Ari Happonen}

Hartnell, C. A., Ou, A. Y., \& Kinicki, A. 2011. Organizational Culture and Organizational Effectiveness: A Meta-Analytic Investigation of the Competing Values Framework: Theoretical Suppositions. Journal of Applied Psychology, 96(4): 677-694.

http://doi.org/10.1037/a0021987

Hofstede, G., Neuijen, B., Ohavy, D. D., \& Sanders, G. 1990. Measuring Organizational Cultures: A Qualitative and Quantitative Study Across Twenty Cases. Administrative Science Quarterly, 35(2): 286-316.

http:/doi.org/10.2307/2393392

Hogan, S. J., \& Coote, L. V. 2014. Organizational Culture, Innovation, and Performance: A Test of Schein's Model. Journal of Business Research, 67(8): 1609-1621.

http://dx.doi.org/10.1016/j.jbusres.2013.09.007

Holmström, J., Främling, K., \& Ala-Risku, T. 2010. The Uses of Tracking in Operations Management: Synthesis of a Research Program. Production Economics, 126(2): 267-275.

http://doi.org/10.1016/j.ijpe.2010.03.017

Homburg, C., \& Pflesser, C. 2000. Multiple-Layer Model of MarketOrientated Organizational Culture: Measurement Issues and Performance Outcomes. Journal of Marketing Research, 37(4): 449-462.

https://doi.org/10.1509/jmkr.37.4.449.18786

Hult, T. G. M., Hurley, R. F, \& Knight, G. A. 2004. Innovativeness: Its Antecedents and Its Impact on Business Performance. Industrial Marketing Management, 33(5): 429-438.

http://doi.org/10.1016/j.indmarman.2003.08.015

Igo, T., \& Skitmore, M. 2005. Diagnosing the Organizational Culture of an Australian Engineering Consultancy Using the Competing Values Framework. Construction Innovation, 6(2) 121-139. https://doi.org/10.1108/14714170610710659

Kajanus, M., Iire, A., Eskelinen, T., Heinonen, M., \& Hansen, E. 2014. Business Model Design: New Tools for Business Systems Innovation. Scandinavian Journal of Forest Research, 29(6): 603-614. http://doi.org/10.1080/02827581.2014.949301.

Kalliath, T. J., Bluedorn, A. C., \& Gillespie, D. F. 1999. Confirmatory Factor Analysis of the Competing Values Instrument. Educational and Psychological Measurement, 59(1): 143-158. https:// doi.org/10.1177/0013164499591010

Koplyay, T., Chillingworth, L., \& Mitchell, B. 2013. Corporate Lifecycles: Modelling the Dynamics of Innovation and Its Support Infrastructure. Technology Innovation Management Review, 3(10): 22-29. http://timreview.ca/article/733

Lakiza, V., Deschamps, I., \& Brodeur, J. 2017. Propelling Innovation: The Role of Intrapreneurial Culture and Performance Measurement. Paper presented at the ISPIM Innovation Forum, Toronto, Canada, March 19-22 March 2017.

Lamond, D. 2003. The Value of Quinn's Competing Values Model in an Australian Context. Journal of Managerial Psychology, 18(1): 46-59. http://doi.org/10.1108/02683940310459583

Lavine, M. 2014. Paradoxical Leadership and the Competing Values Framework. The Journal of Applied Behavioral Science, 50(2): 189-205.

https://doi.org/10.1177/0021886314522510
Lincoln, S. 2010. From the Individual to the World: How the Competing Values Framework Can Help Organizations Improve Global Strategic Performance. Emerging Leadership Journeys, 3(1): 3-9.

Macdonald, S., Assimakopoulos, D., \& Anderson, P. 2007. Education and Training for Innovation in SMEs: A Tale of Exploitation. International Small Business Journal, 25(1): 77-95. https://doi.org/10.1177/0266242607071782

Martins, E. C., \& Terblanche, F. 2003. Building Organizational Culture that Stimulates Creativity and Innovation. European Journal of Innovation Management, 6(1): 64-74. https://doi.org/10.1108/14601060310456337

Mathieu, J. E., Heffner, T. S., Goodwin, G. F., Salas, E., \& CannonBowers, J. A. 2000. The Influence of Shared Mental Models on Team Process and Performance. Journal of Applied Psychology, 85(2): 273-283. http://doi.org/10.1037/0021-9010.85.2.273

Matinaro, V., \& Yang, L. 2017. Towards Innovativeness and Sustainability through Organizational Culture: A Case Study of a Finnish Construction Business. Journal of Cleaner Production, 142(4): 3184-3193. http://dx.doi.org/10.1016/j.jclepro.2016.10.151

Meyerson, D., \& Martin, J. 1987. Cultural Change: An Integration of Three Different Views. Journal of Management Studies, 24(6): 623-647.

Miettinen, S. 2017. Introduction to Industrial Service Design. London: Routledge.

Mudambi, R., Mudambi, S. M., \& Navarra, P. 2007. Global Innovation in MNCs: The Effects of Subsidiary Self-Determination and Teamwork. Journal of Product Innovation Management, 24(5): 442-455. http://doi.org/10.1111/j.1540-5885.2007.00262.x

Naranjo Valencia, J. C., Sanz Valle, R., \& Jiménez Jiménez, D. 2010. Organizational Culture as Determinant of Product Innovation. European Journal of Innovation Management, 13(4): 466-480. http://doi.org/10.1108/14601061011086294

Ogbonna, E. 1992. Managing Organizational Culture: Fantasy or Reality? Human Resource Management Journal, 3(2): 42-54. http://doi.org/10.1111/j.1748-8583.1992.tb00309.x

Ogbonna, E., \& Harris, L.C. 2000. Leadership Style, Organizational Culture and Performance: Empirical Evidence from UK Companies. International Journal of Human Resource Management, 11(4): 766-788. http://dx.doi.org/10.1080/09585190050075114

Pries-Heje, J., \& Baskerville, R. L. 2010. Management Design Theories. In Proceedings of the IFIP Working Conference on Human Benefit through the Diffusion of Information Systems Design Science Research: 263-281. Berlin: Springer.

Quinn, R. E., Hildebrandt, H. B., Rogers, P.S ., \& Thompson, M. P. 1991. Competing Values Framework for Analyzing Presentational Communication in Management Context. Journal of Business Communication, 28(3): 213-232. https://doi.org/10.1177/002194369102800303

Ragan, T. 2013. Q\&A. How Do You Program Innovative Thinking into Company Culture? Technology Innovation Management Review, 3(10): 44-47. http://timreview.ca/article/736 


\section{Effects of Business Model Development Projects on Organizational Culture}

Ulla Santti, Tuomo Eskelinen, Mervi Rajahonka, Kaija Villman, and Ari Happonen

Rajwani, T., \& Liedong, T. A. 2015. Political Activity and Firm Performance within Nonmarket Research: A Review and International Comparative Assessment. Journal of World Business, 50(2): 273-283.

http://dx.doi.org/10.1016/j.jwb.2014.10.004

Schein, E. 1984. Coming to A New Awareness of Organizational Culture. Sloan Management Review, 25(2): 3-16.

Schein, E. 1985. Organizational Culture and Leadership: A Dynamic View. San Francisco, CA: Jossey-Bass.

Schein, E. 1990. Organizational Culture. American Psychologist, 45(2): 109-119.

http://psycnet.apa.org/doi/10.1037/0003-066X.45.2.109

Smircich, L. 1983. Concepts of Culture and Organizational Analysis. Administrative Science Quarterly, 28(3): 339-358. http://doi.org/10.2307/2392246

Tsui, A. S., Zhang, Z., Wang, H., Xin, K. R., \& Wu, J. B. 2006. Unpacking the Relationship Between CEO Leadership Behavior and Organizational Culture. The Leadership Quarterly, 17(2): 113-137. http://doi.org/10.1016/j.leaqua.2005.12.001

van Muijen, J. J., Koopman, P., De Witte, K., De Cock, G., Susanj, Z., Lemoine C., Bourantas, D., Papalexandris, N., Branyicski, I., Spaltro, E., Jesuino, J., Das Neves, J.G., Pitariu, H., Konrad, E., Peiro, J. González-Romá, V., \& Turnipseed, D. 1999. Organizational Culture: The Focus Questionnaire. European Journal of Work and Organizational Psychology, 8(4): 551-568. http://dx.doi.org/10.1080/135943299398168

van Vuuren, M., Veldkamp, B. P., de Jong, M. D.T., \& Seydel, E. R. 2007. Why Work? Aligning Foci and Dimensions of Commitment along the Axes of the Competing Values Framework. Personnel Review, 37(1): 47-65.

https://doi.org/10.1108/00483480810839969

Yu, T., \& Wu, N. 2009. A Review of Study on the Competing Values Framework. International Journal of Business and Management, 4(7): 37-42.

http://dx.doi.org/10.5539/ijbm.v4n7p37

Citation: Santti, U., Eskelinen, T., Rajahonka, M., Villman, K., \& Happonen, A. 2017. Effects of Business

Model Development Projects on Organizational Culture:

A Multiple Case Study of SMEs. Technology Innovation

Management Review, 7(8): 15-26.

http://timreview.ca/article/1096

Keywords: organizational culture, competing values framework, development project, SME, business model, business model canvas, service design 